\title{
Managers' information literacy: a case study of a cluster in Brazil
}

\section{A Competência em Informação dos Gestores: um estudo de caso de um cluster no Brasil \\ La Alfabetización Informacional de los Gestores: un estudio de caso de cluster en Brasil}

\author{
Selma Leticia Capinzaiki Ottonicar ${ }^{1}$ Marta Lígia Pomim Valentim² Glória Georges Feres ${ }^{3}$ \\ 1 Ph.D. Candidate in Information Science at Sao Paulo State University - UNESP, Brazil. https: / orcid.org / 0000-0001-6330-3904 \\ 2 Universidade Estadual Paulista Júlio de Mesquita Filho (Unesp), Marília, São Paulo, Brasil. https: / / orcid.org/ 0000-0003-4248-5934 \\ ${ }^{3}$ Universidade Estadual Paulista Júlio de Mesquita Filho (Unesp), Marília, São Paulo, Brasil. https: / / orcid .org/ 0000-0001-5156-5384
}

Mail to/Autor para correspondência/Correo a:Selma Leticia Capinzaiki Ottonicar, selma.leticia@hotmail.com

Funding/Financiamento/Financiamiento: Coordenação de Aperfeiçoamento de Nível Superior - CAPES

Copyright (c) 2018 Ottonicar, S. L. C.; Valentim, M. L.; Feres, G. G.. All journal content (including directions, editorial policy and templates) is under a Creative Commons license Attribution-NonCommercial-ShareAlike 3.0 Non Adapted. By being published by this journal, articles are free to use in educational, research and non commercial environments, with mandatory attribution of authorship. To further information check http://revistas.ufpr.br/atoz/about/submissions\#copyrightNotice.

\begin{abstract}
Introduction: Managers need to be information literate to take effective decisions.

Objectives: This study aims to analyze the situation of information literacy in small businesses organized as clusters and develop a case study about the electronics industrial cluster in the city of Garça, Sao Paulo State.

Method: A literature review supported the elaboration of theory about information literacy; documentary research to characterise the historical research universe; and a case study, covering a set of eleven (11) small companies in the electronics sector.

Results: The managers value information, knowledge and lifelong learning. However, they do not understand that information literacy influences competitive advantage. The results demonstrate that information literacy is an influential factor in the business competitiveness of these organizations and therefore effectively contributes to the survival of companies in the market. Information literacy contributes directly to small businesses' growth organized as a cluster.

Conclusions: Managers rely on a group to share information. Furthermore, they evaluate information to create innovation through creativity.

Keywords: Information Literacy; Cluster; Small Businesses; Competitiveness; Lifelong Learning; Electronic Industry.
\end{abstract}

\section{Resumo}

Introdução: Os gestores necessitam ser competentes em informação para tomar decisões eficazes.

Objetivos: Essa pesquisa objetiva analisar a situação da competência em informação em micro e pequenas empresas organizadas como clusters e desenvolver um estudo de caso sobre um cluster de eletroeletrônicos da cidade de Garça, São Paulo.

Método: A revisão da literatura apoiou a elaboração sobre as teorias de competência em informação, uma pesquisa documental foi realizada para caracterizar o universo de pesquisa e um estado de caso cobrindo onze (11) empresas de micro e pequeno porte do ramo de eletroeletrônicos.

Resultados: Os gestores valorizam informação, conhecimento e aprendizado ao longo da vida. Entretanto, eles não compreendem que a competência em informação contribui com a competitividade. Os resultados demonstram que a competência em informação é fundamental para a competitividade do cluster e, portanto, contribui com a sobrevivência das organizações no mercado. Além disso, contribui com o crescimento das micro e pequenas empresas que formam o cluster.

Conclusão: Eles confiam no grupo, avaliam a informação para criar a inovação por meio da criatividade.

Palavras-chave: Competência em informação; Clusters; Micro e pequenas empresas; Competitividade; Aprendizado ao longo da vida.

\section{Resumen}

Introducción: Los gestores necesitan ser competentes en información para tomar decisiones eficaces.

Objectivos: Esta investigación objetiva analizar la situación de la alfabetización informacional en micro y pequeñas empresas organizadas como clusters y desarrollar un estudio de caso sobre un cluster de electroelectrónicos de la ciudad de Garça, São Paulo.

Metodología: La revisión de la literatura apoyó la elaboración sobre las teorías de la alfabetización informacional, una investigación documental fue realizada para caracterizar el universo de investigación y un estado de caso cubriendo once (11) empresas de micro y pequeño porte de la rama de electro electrónicos.

Resultados: Los gestores valoran la información, el conocimiento y el aprendizaje a lo largo de la vida. Sin embargo, ellos no entienden que la alfabetización informacional contribuye a la competitividad. Los resultados demuestran que la alfabetización informacional es fundamental para la competitividad del cluster y, por lo tanto, contribuye con la supervivencia de las organizaciones en el mercado. Además, contribuye al crecimiento de las micro y pequeñas empresas que forman el cluster.

Conclusiones: Ellos confían en el grupo, evalúan la información para crear la innovación a través de la creatividad.

Palabras clave: Alfabetización informacional; Cluster; Micro y pequeñas empresas; Competitividad; Aprendizaje a lo largo de la vida.

\section{INTRODUCTION}

Michael Porter was the creator of the term cluster which was introduced in his book The Competitive Advantage of Nations. Cluster was associated with the fusion of similar objects. The management field has adopted it 
to refer to a group of organizations that compete internationally. It can also exist even if the members of the system don't recognise it. The group in a geographic area develops the activities of this system naturally, and these activities result in competitiveness (Zaccarelli, 2008).

The cluster is not necessarily a formal system; the competitiveness does not emerge from separate organizations, and executives don't acquire an 'extra competence' to achieve their goals (Zaccarelli, 2008, p. 66). Managers of a cluster need to access, evaluate and use information daily, so they become information literate to make a decision and solve problems effectively. Information literacy: "[...] enables individuals to access, select, manage and evaluate information needed by professional, social and personal life" (Belluzzo \& Feres, 2015, p. 8).

International organizations like the Association of College and Research Libraries (ACRL) and the International Federation of Library Associations and Institutions (IFLA) created standards and indicators to identify people's information literacy. Belluzzo (2007) developed standards, indicators and results of information literacy which are suitable to the context of Brazilian organizations. Belluzzo's standards, indicators and results were adapted to investigate information literacy in the context of clusters.

The research problems which guided the research are: why are small businesses organized in clusters and how does this structure influence competitiveness? Is managers' information literacy a competitive factor in electronics businesses organized as clusters? What is the relationship between information literacy and the competitiveness of those businesses?

The purpose of this research was to analyze the characteristics and the situation of managers' information literacy as a competitive advantage. Those managers work in the strategic level in small businesses organized as a cluster. This study was developed in the electronics sector in the city of Garça which is considered an industrial complex of technology in security and automation.

This study is qualitative, based on a literature review and a case study. The case study proposed by Yin (2010) was chosen because it provides the collection of distinct evidence so it was possible to apply the triangulation technique (Yin, 2010). The tools used to collect data were the interview with the manager of Commercial and Industrial Association of Garça (ACIG), a questionnaire answered by eleven strategic managers and document analysis regarding to ACIG and the cluster. The triangulation between documental research, interview and questionnaire provided reliable and valid results.

This research is based on a voluntary and intentional sample, since the manager of the association (who answered an interview) and eleven small business managers of the electronics industry (who answered the questionnaire) participate in the cluster. Managers were contacted personally by the researcher. They agreed to cooperate with this research voluntarily. The researcher presented a letter about this study and an informed consent form. Furthermore, the anonymity of participants was preserved.

This documental research contributed to construct the theory. Furthermore, it helped to understand the cluster. Those documents showed the importance of the cluster to the city of Garça, how it was created, and its operations. The analysis of official documents was provided by Industry and Commerce Municipal Office (SEMIC), by the Historical and Pedagogical Museum of Garça (MPHG), by the Municipal Archive and by the Commercial and Industrial Association of Garça (ACIG). Internet sources were researched: the ACIG and the Business Incubator websites.

A script was developed to guide the interview with fourteen questions. That interview was made with the (one) manager of ACIG. He was selected because he helps the managers of the cluster. He received an invitation letter to give an interview. Furthermore, the interview was based on 14 (fourteen) questions in which 4 (four) focused on the manager's business context. The other questions aimed to understand the business association and the cluster.

The questionnaire had three open questions and twenty-six questions based on Likert Scales. There are eleven (11) companies which are associated to ACIG. Every strategic manager is encouraged to participate in meetings and courses provided by the cluster association. Because of that, those eleven strategic managers were chosen to answer the questionnaire.

In the first part of the questionnaire, there were 3 (three) open questions to understand the managers' job and the company. It was answered by 11 (eleven) managers who work on electronic organizations in the city of Garça. The second part of the questionnaire was structured by Likert Scale. It had 26 (twenty-six) questions based on Belluzzo's standards and indicators (2007). The number 1 is the lowest level of the scale and it means total disagreement. The level 5 is the highest in the scale and it means total agreement.

\section{FINDINGS AND DISCUSSION}

In the 1980s, Garça municipal politicians realized the electronics sector was an excellent economical alternative. Because of that, the First Industrial District was created. Garça is an electronics industrial pole, and it is also 
known as the biggest electronic gate producer. Those companies advance in the technological progress and market share for example, lamp reactors, nobreak, electric motors, plastic injection, aluminum injection, metallic stamps, steel, bronze and plastic engineering (SEMIC, 2014).

The electronics companies employ people and generate incomes for the city. Garça is known as an electronics pole nationally. The city has an excellent educational network: one public college named Faculdade de Tecnologia de Garça (FATEC) and two private colleges, Ensino Superior de Garça (IESG) and Faculdade de Agronomia e Engenharia Florestal (FAEF). There are also two technical schools, ETEC "Monsenhor Antônio Magliano" and Escola Agrícola "Deputado Paulo Ornellas".

The installation of the aforementioned schools demonstrates the necessity of a specialized workforce to fill labor niches offered by electronics companies. The demand for labor arises from the emergence and growth of electronics companies. They were chosen in this research because they are numerous in Garça. Garça currently has 150 companies. Manufacturing industries are the sector which creates the plurality majority of jobs for citizens. There are 4020 work positions, which represents 35,6\% of workers (SEMIC, 2014). It also has ten different industry segments.

The city offers tax incentives, land donation, tax exemption and infrastructure assistance. Because of that, the city stimulates the creation of new companies and the development of existing companies (MHPG, 2014).

After an analysis of a list of organizations provided by ACIG, only 11 companies are part of the electronics sector. The other companies do not manufacture electronic products. Some of them only sell electronic products and others are part of dental and telecommunications industry. Because of that, the scope of this research was formed by the 11 (eleven) small businesses which are part of the electronics sector and are associated to ACIG.

The city has a business incubator named 'Alfeu Rosário', and it was inaugurated on September 6th, 1996. A partnership was made between the City Hall and the Federation of São Paulo State industries (FIESP). The incubator has 24 adapted rooms and an infrastructure to support small business. Also, the incubator offers courses, training, consultancy and advice which contribute to the growth and development of incubated companies(MHPG, 2014).

There is collaboration between ACIG, Serviço Brasileiro de Apoio a Micro e Pequenas Empresas (SEBRAE) and the City Hall. This fact gives credibility to the system, and it also enables the incubator to perform local cooperation. For example, there is a partnership with the colleges FATEC, FAEF and IESG, so the incubator process is advertised around the region (MPHG, 2014). That cluster is composed of political, economic and social aspects.

The ACIG has a manager who has responsibilities such as managing the organization's members, managing the business incubator in Garça and building relationships with the members. In addition, he is responsible to plan and facilitate the board of directors meeting that happens every fifteen days. The board of directors is composed of 17 (seventeen) appointed directors and 5 (five) elected directors to occupy the position.

He showed that information is very important to daily performance. It provides conditions to predict how the sectors' sales will be in the future. Furthermore, the word information was mentioned several times by the manager of the association, which demonstrates it is essential at work. It is also important to directors' information sharing in public and private organizations which are involved with the electronics cluster of the city of Garça. So, information provides a vision of the future to contribute to the decision-making process.

The ACIG manager understands information literacy as a synonym of working information, since it is obtained and used to prevent future events. He illustrated that some information is not communicated but is stored to be accessed later.

The manager mentioned that the ACIG is important to the city because it provides information to managers who work in the small electronics companies. He also arranges meetings with the human resources managers of the medium-sized organizations every month. The small businesses do not have a formal human resources department, because most of them are family businesses.

During the meetings there are members of the electronics, food, chemical and other economic sectors. The association represents the managers of Garça and allows them to join forces to face the current international crisis. They seek solutions at the City Hall, federal agencies, state government, institutions and other cities.

There are procedures of information sharing during the meetings among business managers and others involved. Yet the decisions made in a group may or may not be implemented, so they depend on the managers' decisionmaking. It would be important to have other means which stimulate the information sharing and consolidate the group's decision.

The manager believes that the 'visualisation of the future' is the most important skill; the individual should develop their vision of future situations. This is useful to plan actions to guide the companies during economic changes. The electronics companies are surviving through a difficult time. However, the managers who were 
prepared for this are suffering fewer consequences. Visualising future situations is considered to be the most important skill of the cluster. According to him, the managers who know how to deal effectively with information are more likely to survive in the current economic crisis.

Information literacy is a much more complex subject than the ACIG manager believes. However, he demonstrates a superficial understanding about it, since he mentioned to work with information which means access, evaluate and use information in an intelligent way.

The most important factor which influences competitiveness is the small businesses which provide feedstock to medium-sized companies. So, the medium-sized businesses do not need to produce every part and tool. They buy the parts with little shipment cost, since the supplier is located in the same city. The cluster itself stimulates competitiveness to the companies of Garça and because of that the city is known as an electronics industrial centre. He stated that the organizations are inside of a system in which they are suppliers and clients at the same time. They depend on each other, and this system stimulates the economy of the city. On the other hand, it is a worrying factor to ACIG because this dependency may create a limited system. He explained that it is important that small businesses sell products to a wider market and not only within the cluster.

The manager affirmed that the ACIG stimulates the development of managers' information literacy, since the association offer training courses. It aims to help companies to improve their intellectual capital. The manager believes that the courses contribute to the development of employees' skills based on the market context. That training is also offered to society in general.

The manager also said that the ACIG helps to develop the city, especially the electronics industry because it provides local jobs. The ACIG allows managers to share information in order to know how to compare products, which decision to take and how to face Chinese competition.

The electronics industry contributes significantly to Garça and also employs people who live in the region. Michael Porter, the creator of the term cluster, found out in different countries that the geographic concentration is related to the city competitiveness. That is the reason why Garça is considered a technological, electronic, security and automation industrial centre.

The manager emphasised that there are several benefits to the organization of businesses in clusters. The discussions among managers, ACIG and the city hall aim to consolidate a dynamic structure. This enables companies to survive and be more competitive in the market.

In the interview with the manager of ACIG he mentioned the term 'information' several times. Information is fundamental at work; it allows its sharing among the managers and public organizations which participate in the electronic cluster in Garça.

In the first part of the questionnaire, every manager considered their company as important to the city of Garça. They explained that these organizations create employment, generate income, and promote the city around the country. According to Scheffer, Cário and Ederle (2006) one of the clusters' advantages is that they employ local people.

The managers of the organizations B, E, F, H, J and K said that the company did not receive government benefits. However, the City Hall helps companies to leave the business incubator to install themselves in the industrial district. All of these companies were in the business incubator website as a "graduate company", which means they were part of the incubator process. Furthermore, company B received subsidized land in the Industrial District. The documental research at the Historical and Pedagogical Museum of Garça (2014) demonstrated that the city provides tax incentives. It also donates land, provides tax exemption, and supports infrastructure.

The manager is a reliable source of information, because he can use his knowledge, capacity, ability and experiences to seek information. Therefore, we suggest that managers may adopt strategies to use knowledge to recognize and supply information needs.

Most of these companies are considered small businesses (they have a balance sheet less than 360,000 reals in Brazil). Together they employ 239 (two hundred and thirty-nine) people. The managers who answered the questionnaire work at the strategic level and some of them are business owners. The strategic level is focused on organization survival, and because of that they seek new strategies and niche markets which guarantee competitive advantage to the company. Information literacy is defined in this research as a fundamental element of competitiveness, especially for the electronics companies of Garça.

Only 11 (eleven) electronics companies are members of ACIG, and even though it is a small number, they employ local workers. Every company has a different goal which is complemented in the cluster. Furthermore, they produce different products which are sold to other electronics companies. For example, company E produces electric cables and company I produces printed circuit boards. Both of them are basic devices which are bought by the organizations. 
In short, their missions and goals are concentrated on electronic products to satisfy the clients' needs. There is an agreement among managers about the importance of the companies to Garça: since they generate job opportunities, they contribute to development of the city. They also improve the reputation of Garça, considered by ACIG and Industry and Commerce Municipal Office to be a security and automation industrial pole.

The data triangulation allowed interpretation of the cluster context. Most of the industries were founded since 2000 and hence have sixteen years or less in the market. So they are too new to have enough strength to compete in this environment. Every company has a different goal in the cluster, so they complement each other. They produce different products which can be sold to another electronics company. For example, company ' $E$ ' produces electric whips which are used by the other companies and company ' $\mathrm{I}$ ' produces printed circuit boards that is a basic component of electronic products.

The electronics companies of Garça created a cluster to improve their competitiveness at the market. According to Porter (1999), Zaccarelli (2008), Molina (2013) and Scheffer, Cario and Enderle (2006) the group makes the small businesses stronger because together they get government funding and greater visibility.

Despite the fact that the companies in the cluster are clients and suppliers among themselves, there is a competition between them, because some sell similar products. That fact demonstrated the complexity of the industry of Garça, because they unite to pressure the City Hall, share information and also compete. Molina (2013) explains that a surprising fact about the clusters is that they are differentiated by the competition. That does not happen with the cluster, which is the business group marked by cooperation.

They all agree about the importance of electronics companies to the city of Garça. Those organizations generate jobs and income and contribute to the growth of the city. The ACIG and Industry and Commerce Municipal Office consider Garça an industrial centre of electronic security and automation. Eight believe that its importance is related to job creation.

Four managers said that the incomes are the main advantages and three identified that these industries 'make Garça famous' in other states of Brazil. The small businesses contribute to the development of local economy, since they create jobs, allow innovation investments, add value to human capital and construct a knowledge-sharing network (Molina, 2013; Porter, 1993; Scheffer et al., 2006; Zaccarelli, 2008). They made the city attractive to financial and educational investments, and they stimulate the creation of technical schools, professional courses and universities (Molina, 2013).

According to Industry and Commerce Municipal Office (2014) most producers of electronic gates (such as automatic garage doors) are located in the city of Garça. The sector advances every day in every electronic security product such as electrical ballast, power supplies, electric motors, plastic injection mold, aluminium injection, stamping, production of steel, bronze and plastic engineering.

The words job, income and fame are elements that influence competitiveness in the market. Nine managers affirm that they didn't receive any benefit from the state or city government, while two received a land donation and only one acknowledged that his company participated in the business incubator.

Scheffer, Cário e Enderle (2006) demonstrated that the companies which organize in clusters can get subsides from the government. The municipality offers a business incubator project known as Business Development Centre Alfreu Rosário and they have a website to provide information about it. Some industries received benefits from the city, others are assisted by the SEBRAE, and others received credit from the National Bank for Economic and Social Development (BNDES) and the Machine and Equipment Fund (FINAME). Company 'G' used these benefits as well as tax credits and received land in the Industrial District of Garça.

In the documental research (MPHG, 2014) the incubator is relevant because it houses new organizations and entrepreneurs, so they can compete in the global business market. They also survive because it offers courses, training, consulting and advice which contribute to their growth and development. These courses can be useful for the employees of every company, since they share the costs of training. There is the development of collective learning through information sharing. Corsatto and Hoffman (2013) explain that the network encourages knowledge sharing in the business context. Dias and Belluzzo (2003) agree with Cosatto and Hoffman (2013) because the access of many information sources such as networks and information services help to improve competitiveness.

Information literacy contributes directly to small businesses' growth when organized as a cluster. They rely on a group, evaluate information to create innovation through creativity and survive in the market. Although the cluster does not research nor develop innovation products with universities, the businesses hire students from Instituição de Ensino Superior de Garça (IESG), Faculdade de Agronomia e Engenharia Florestal (FAEF) and FATEC (local colleges) to act in specific fields.

The emergence of those schools indicates that the cluster attracted them and values knowledge. Purington, Butler and Gale (2003) illustrated that the knowledge valorization is a result of an abstract economy, and 
humans are elements that create wealth. Choo (2006) demonstrated that the organization generates, processes and organizes information to create knowledge through learning.

The companies and ACIG support skill development of employees according to the market needs. They offer courses and training. The managers considered information as a key element to routine activities. Although managers had differences with respect to understanding the concept of information literacy, they understood its elements. They recognise the importance of information, knowledge, innovation, competitiveness and lifelong learning.

Miranda (2004) says that information is a production factor, and because of that, there is a specific type of skill to manage information in organizations. Furthermore, there are people who study to work with information. Belluzzo (2007) interprets that information literacy is formed by two dimensions. The first one is a set of knowledge and abilities that encourages a practical approach. The second is related to a critical vision of the social context. The managers affirmed they know the meaning of information literacy; however they did not connect it with competitiveness. Their concept is partial, and this was expected because information literacy is a concept studied by information science, and it is not known by the business field.

The use of the standards and indicators should be encouraged by the ACIG manager in the periodic meetings with other managers. Information literacy is essential to strategic level activities, since the goals are determined from information available from the market analysis. The ACIG can use courses and training to promote information literacy, so members could develop the ability to identify their information needs and to access, evaluate and use information. Managers should understand the social and economic issues which affect the information use to achieve a goal and survive in a crisis period.

Eisenberg (2008) explains that information literacy involves knowledge and abilities which stimulate people to seek, evaluate, use and filter information. Belluzzo (2006) explains that information literacy requires the use of thought to solve problems and achieve goals through arguments based on evidence.

The managers should value information literacy in their daily activities and consider information reliability and quality for efficient decision-making. Intelligent information use is not innate, so individuals need to develop abilities, learn from experience and incorporate that into their behaviour.

The small electronics businesses organized as a cluster have a competitive advantage, because the managers of those companies have characteristics of information literacy. This conclusion is based on the questionnaire analysis, and in the context of those companies, information literacy is a daily element, so it influences organizational development. Information literacy contributes to companies, especially to help them pass through a crisis period and to survive in a competitive market.

Vitorino and Piantola (2011) illustrated that information literacy is formed by abilities to search, evaluate and use information which individuals need. Furthermore, it is connected to the idea of succesful access and new technology use. McGee and Prusak (2004) explain that information influences strategy development. Both information and information communication technology are fundamental to competitive advantage for businesses.

The information literate person accesses, evaluates and uses information in an intelligent way. This person is not easily deceived by misinformation. Information contributes to knowledge creation, which stimulates individual creativity (the cognitive process). When individuals put creativity into practice, they obtain innovation. That innovation supports the company's growth by winning new clients. Information literacy, innovation and competitiveness are connected in a way that establishes a link of cause and effect.

The triangulation of the interview, questionnaires and documental research illustrated that the managers and ACIG manager value information and knowledge. However, most of them do not know how to evaluate the information source. The managers should be aware that information reliability influences decision-making and competitive advantage.

The strategies to identify the information needs and access, process, organise, use, disseminate and analyze information are essential to small business' strategic level. They are important because the manager is responsible for finding gaps in the market and attracting new customers.

Furthermore, information sharing is an important action, and it should be used frequently by the companies so they will use information in an effective way. Therefore, the association manager should inspire a culture of information dissemination among the group members. He could encourage other managers to be aware of the importance of learning through information seeking to build knowledge.

\section{CONCLUSIONS}

The purpose of this paper was to analyze the situation of information literacy in small businesses organized as clusters and develop a case study about the electronics industrial cluster in the city of Garça. Managers 
develop some actions which correspond to information literacy standards and indicators. However, they have some difficulty to acess and evaluate information.

The association is in the centre of the cluster, and it is the main means of information sharing among the companies. It also helps managers to solve problems in a group, even though they compete in the market. The literature analysis and the interpretation of exploratory study results (interview and questionnaire) reveal the need for abilities that should be developed by the managers. These skills are related to information access in order to strengthen the cluster.

This research is fundamental to society because it illustrates that information literacy may contribute to clusters' economic development. As a result, competitiveness increases and companies hire more local workers. Furthermore, information literacy stimulates managers to become lifelong learners, so they value both information and knowledge to develop their professional activities.

This paper is limited because it only considered one cluster. Future research can use Belluzzo's standards and indicators (2007) (2007) to develop an information literacy course to stimulate innovation and achieve business competitiveness. Furthermore, researchers can develop comparative a study between clusters to demonstrate how managers experience information literacy.

\section{ACKNOWLEDGMENT}

To Coordenação de Aperfeiçoamento de Nível Superior - CAPES for the scholarship provided to develop this research. 


\section{REFERENCES}

Belluzzo, R. C. B. (2006). O uso de mapas conceituais e mentais como tecnologia de apoio à gestão da informação e da comunicação: uma área interdisciplinar da competência em informação. RBBD. Revista Brasileira de Biblioteconomia e Documentação, 2(2).

Belluzzo, R. C. B. (2007). Construção de mapas: desenvolvendo competências em informação e comunicação. Cá entre nós.

Belluzzo, R. C. B., \& Feres, G. G. (2015). Competência em informação, redes de conhecimento e as metas educativas para 2021: reflexões e inter-relações. Redes de conhecimento e competência em informação: interfaces da gestão, mediação e uso da informação/organização. Rio de Janeiro: Interciência, 1-35.

Choo, C. W. (2006). A organização do conhecimento: como as organizações usam a informação para criar significado, construir conhecimento e tomar decisões. Senac São Paulo São Paulo.

Corsatto, C. A., \& Hoffmann, W. A. M. (2013). Gestão do conhecimento e inteligência competitiva: delineamento de estratégias de competitividade e inovação para pequenas empresas. Encontros Bibli: revista eletrônica de biblioteconomia e ciência da informação, 18(38), 19-36.

Dias, M. M. K., \& Belluzzo, R. C. B. (2003). Gestão da informação em ciência e tecnologia sob a ótica do cliente. EdUSC Bauru.

Eisenberg, M. B. (2008). Information literacy: Essential skills for the information age. DESIDOC journal of library $\varepsilon$ information technology, 28(2), 39-47.

Historical and Pedagogical Museum of Garça (MHPG). (2014). Documents about electronic industry of garça.

McGee, J., \& Prusak, L. (2004). Gerenciamento estratégico da informação. Campus.

Miranda, S. V. (2004). Identificando competências informacionais. Ciência da informação, 33(2).

Molina, L. G. (2013). Memória organizacional e a constituição de bases de conhecimento (Tese de doutorado). Programa de Pós-Graduação em Ciência da Informação, Faculdade de Filosofia e Ciências (FFC), Universidade Estadual Paulista (UNESP), Marília.

Porter, M. E. (1993). A vantagem competitiva das nações. Rio de Janeiro: Campus.

Porter, M. E. (1999). Competição: estratégias competitivas essenciais. Rio de Janeiro: Campus.

Purington, C., Butler, C., \& Gale, S. F. (2003). Built to learn: The inside story of how rockwell collins became a true learning organization. AMACOM Div American Mgmt Assn.

Scheffer, J., Cario, S., \& Enderle, R. A. (2006). Tratamento teórico-analítico sobre empresas de pequeno porte organizadas na forma de aglomeração produtiva localizada. Textos de Economia, 9(2), 49-77.

Secretaria Municipal de Indústria e Comércio (SEMIC). (2014). Documents about electronic industry of garça.

Vitorino, E. V., \& Piantola, D. (2011). Dimensões da competência informacional. Ciência da Informação, $40(1)$.

Yin, R. K. (2010). Estudo de caso: Planejamento e métodos. Bookman editora.
Zaccarelli, S. B. (2008). Clusters e redes de negócios: uma nova visão para a gestão dos negócios. Editora Atlas SA.
How to cite this article (APA):

Ottonicar, S. L. C., Valentim, M. L. \& Feres, G. G. (2018). - AtoZ: novas práticas em informação e conhecimento, 7(1), 4-11. Retrieved from: http://dx.doi.org/10.5380/ atoz.v7i1.62304 